\title{
PRIORITAS ARAH PENEMPATAN TITIK PENGAMATAN KECEPATAN VERTIKAL DI KALIMANTAN MENGGUNAKAN ANALISIS ANISOTROPI
}

\author{
Muhammad Gilang Ramadhan", Ayuna Santika Putri, \\ Andang Kurniawan, Amir Mustofa Irawan \\ Sekolah Tinggi Meteorologi Klimatologi dan Geofisika, Tangerang Selatan \\ *Email: blackangeldjimbas11@gmail.com
}

\begin{abstract}
ABSTRAK
Keberadaan hutan sebagai paru-paru dunia berperan penting dalam menghasilkan gas oksigen. Pulau Kalimantan merupakan salah satu paru-paru dunia karena luas hutannya yang mencapai 40,8 juta hektar. Namun, pada saat ini kualitas dan kuantitas hutan di Pulau Kalimantan mengalami penurunan drastis akibat adanya deforestasi dan kebakaran hutan. Kebakaran hutan di Pulau Kalimantan menjadi sorotan dunia karena persebaran asapnya menyebabkan polusi udara di berbagai wilayah Indonesia. Dampak dari persebaran asap kebakaran hutan dipengaruhi oleh kecepatan angin vertikal pada daerah tersebut. Penelitian ini bertujuan untuk menambah bahan pertimbangan dalam menentukan titik pengamatan kecepatan vertikal angin di Pulau Kalimantan, sehingga dapat diketahui prioritas sebaran penempatan titik pengamatan yang dapat digunakan sebagai upaya mitigasi persebaran asap kebakaran hutan. Data kecepatan angin vertikal Pulau Kalimantan pada bulan Juni sampai Oktober mulai tahun 2008 - 2017 disajikan dalam bentuk spasial. Analisis data angin tersebut menggunakan metode variogram permukaan dengan piranti lunak SAGA. Berdasarkan analisis anisotropi, diperoleh hasil bahwa pengamatan kecepatan vertikal angin di Pulau Kalimantan cenderung mempunyai prioritas arah Timur-Barat pada bulan Juni sampai Agustus, prioritas arah Tenggara-Barat Laut pada bulan September, dan prioritas arah Timur LautBarat Daya pada Bulan Oktober. Analisis dan pemodelan kecepatan angin vertikal pada Pulau Kalimantan secara umum mendapatkan pola dominan prioritas arah Timur-Barat, sehingga prioritas penempatan titik pengamatan kecepatan vertikal pada Pulau Kalimantan efektif jika membentuk pola oval yang memanjang dari Utara ke Selatan.
\end{abstract}

Kata kunci: Pulau Kalimantan, asap, kecepatan vertikal, anisotropi

\begin{abstract}
The existence of the forest as lungs of the world played an important role in generating oxygen gas. Borneo island is one of the world's lungs because of the extensive forests that reached 40.8 million hectares. However, at present the quality and quantity of forest on the island of Borneo precipitously due to deforestation and forest fires. Forest fires on the island of Borneo into the world spotlight because of the spread of the smoke caused air pollution in various regions of Indonesia. The impact of the spread of smoke of forest fires was influenced by the vertical wind speed in the area. This research aims to add a consideration in determining the vertical wind speed observation point on the island of Borneo, making known the priority distribution of the placement of the observation point can be used as mitigation efforts the spread of the forest fire smoke. The vertical wind speed data island of Borneo in June and October starting in $2008-2017$ is presented in the form of spatial. The wind data analysis using the method of variogram surface with the software SAGA. Based on the analysis of anisotropy, obtained the results that the vertical wind speed observations on Borneo Island tend to have priority East-West direction in June to August, the priority of the Southeast-Northwest in September, and priority direction of Northeast-Southwest in October. Analysis and modeling of vertical wind speed on the island of Borneo in general get the dominant patterns of the East-West direction priority, so the priority placement of vertical velocity observations point on the island of Borneo is effective if it forms oval pattern which extends from North to South.
\end{abstract}




\section{PENDAHULUAN}

Kalimantan merupakan pulau yang memiliki lahan gambut yang sangat luas Lahan gambut berfungsi seperti spons menyerap dan menyimpan air dalam jumlah besar, jika tidak mengalami gangguan lahan gambut mampu menyimpan air sebanyak $0.8-0.9 \mathrm{~m}^{3}$ gambut. Di dalamnya terdapat bahan organik yang terdekomposisi secara lambat. Dalam kondisi normal, gambut sangat sulit untuk terbakar. Namun Kanalisasi telah mengubah lahan gambut menjadi mudah terbakar dan kehilangan fungsi sebagai suplai air.

Pulau Kalimantan memiliki potensi kebakaran hutan yang sangat seiring terjadi. Penyebaran asap kebakaran hutan secara umum disebabkan oleh kondisi atmosfer baik secara horizontal maupun vertikal. Asap kebakaran hutan dapat tertahan di daerah kebakaran karena gas asap tersebut lebih berat dari udara normal yang dipengaruhi kondisi atmosfer secara vertikal, sehingga lama-kelamaan asap tersebut akan terakumulasi dan menjadi pekat (BPPT, 1997 dalam Samsul, 2002). Asap kebakaran hutan yang tertahan dapat menyebabkan kabut asap pada suatu daerah. Arah gerak vertikal dari udara yang cenderung ke bawah artinya tidak ada parcel udara yang diangkat naik sehinggga kabut asap semakin mengurangi jarak pandang dan begitu juga sebaliknya (Ika dan Suyatim, 2016).

Pergerakan atmosfer secara vertikal memengaruhi penyebaran asap kebakaran hutan sehingga diperlukan pengamatan yang optimal untuk mendapatkan data kecepatan angin vertikal. Kecepatan vertical adalah nilai untuk mengukur suatu gerakan massa udara dalam bidang vertikal. Pengamatan kecepatan angin vertikal dapat dilakukan menggunakan Pilot Balon. Nilai dari kecepatan vertikal terdiri dari nilai negatif yang menunjukkan pengurangan nilai tekanan per detik dalam bidang vertikal atau terdapat gerakan ke atas dari suatu massa udara, sedangkan nilai positif menunjukkan penambahan nilai tekanan per detik dalam bidang vertikal atau terdapat gerakan turun / ke bawah dari suatu massa udara (Holton, 2004). Kasus kebakaran hutan pada tahun 2015 di Pulau Kalimantan yang menimbulkan kabut asap hingga ke negara lain mendorong penulis untuk mengetahui pola kecepatan vertikal. Kecepatan vertikal pada Pulau Kalimantan dapat diketahui polanya setelah melakukan proses interpolasi spasial pada daerah-daerah di Pulau Kalimantan yang tidak memiliki informasi lengkap mengenai data kecepatan vertikal.

Pola kecepatan vertikal dianalisis menggunakan teknik analisis geostatisitik yaitu metode variogram permukaan. Secara umum, menurut Pratama dkk (2016) metode geostatistik mampu mengolah data yang rumit menjadi mudah dengan cara yang lebih sederhana dan pendekatan yang lebih cepat untuk menentukan pola distribusi spasial dan anomali. Metode variogram dipilih karena metode ini erat hubungannya dengan fungsi jarak seperti yang dijelaskan oleh Plant (2012) dalam Desiwari (2017) bahwa korelasi spasial dapat dimodelkan sebagai suatu fungsi jarak dan didefinisikan sebagai variogram isotropi, sedangkan pemodelan terhadap fungsi jarak dengan mempertimbangkan arah dapat didefinisikan sebagai variogram anisotropi.

Penelitian ini bertujuan untuk mengetahui pola kecepatan vertikal di Pulau Kalimantan yang erat kaitannya terhadap fenomena kabut asap kebakaran hutan sehingga dapat diketahui prioritas sebaran penempatan titik pengamatan. Dengan mengetahui hal tersebut, diharapkan dapat dijadikan sebagai bahan pertimbangan dalam menempatkan titik pengamatan kecepatan vertikal. Sebaran penempatan titik pengamatan yang tepat, dapat digunakan sebagai upaya mitigasi persebaran asap kebakaran hutan.

Kebakaran hutan di Kalimantan menjadi ancaman potensial sistem ekologi, infrastruktur, dan kehidupan manusia, terlebih pada salah satu dampak yang ditimbulkan yaitu berupa asap kebakaran hutan. Asap kebakaran hutan dapat mengganggu kesehatan dan menimbulkan penyakit infeksi saluran pernapasan (ISPA) serta kekacauan lintas penerbangan akibat jarak pandang yang buruk.

\section{TINJAUAN PUSTAKA}

\subsection{Variogram}

Variogram merupakan plot dua dimensi yang digunakan untuk mengukur keragaman spasial antar amatan pada data yang digunakan. Variogram adalah suatu langkah dalam menghitung cakupan/hubungan antara satu poin 
dengan poin lain.Sehingga didapatlah penyebaran atau lokasi yang dipetakan dalam bentuk grid-grid. Variogram tergolong dalam metode analisis secara geostatistik yang berfungsi untuk mengkuantifikasi tingkat kemiripan atau variabilitas antara dua contoh yang terpisah pada jarak tertentu. Data yang dekat dengan titik yang ditaksir memiliki kecenderungan nilai yang lebih mirip dibandingkan data yang lebih jauh. Dalam penelitian Desiwari (2017) dijelaskan bahwa variogram mencerminkan karakteristik dari korelasi spasial, yaitu korelasi antara dua buah amatan menjadi berkurang atau tidak berkorelasi karena bertambahnya jarak antar amatan tersebut (Cressie, 1993). Selanjutnya variogram yang terbentuk diidentifikasi kemiripan terhadap model-model teoritis yang tersedia. Analisis variogram merupakan tahapan dalam perhitungan pada sejumlah lokasi \& melihat hubungan antar observasi pada berbagai lokasi yang diukur.

Secara umum terdapat empat model variogram, baik pada variogram isotropi maupun variogram anisotropi. Model-model tersebut adalah spherical, exponential, gaussian, dan linear. Secara umum, perbedaan antara model sejenis pada variogram isotropi dengan variogram anisotropi terletak pada nilai jangkauan (range). Model untuk variogram isotropi menggunakan nilai jangkauan secara umum, sedangkan model untuk variogram anisotropi menggunakan tambahan komponen arah pada perhitungan nilai jangkauannya (Yulhendra dan Anaperta, 2013). Model yang paling sesuai dengan hasil variogram yang terbentuk merupakan model yang dipilih pada variogram tersebut.

\subsection{Anisotropi}

Berkenaan dengan isotropi dan anisotropi, analisis geostatistik menggunakan variogram untuk menyajikan korelasi variabilitas spasial. Model variogram adalah fungsi jarak. Jika variogram varians spasial hanyalah fungsi jarak dan variabilitasnya tidak bervariasi sesuai dengan arahan spasial, ini disebut "Isotropi". Jika variabilitasnya bervariasi sesuai dengan arahan spasial, ini disebut "Anisotropi". Dengan kata lain, model variogram anisotropik adalah fungsi "jarak" dan "arah", dan persamaannya dapat disajikan sebagai berikut: $\gamma(h, \theta)=\left(\frac{1}{2} N(h, \theta)\right) \sum_{i=1}^{N(h, \theta)}\left[z\left(x_{i}\right)-z\left(x_{i}+h, \theta\right)\right]^{2}$

$\theta \quad$ : sudut sepanjang titik $\mathrm{X}_{\mathrm{i}}$ dan $\mathrm{X}_{\mathrm{i}+\mathrm{h}}$

$N(h \theta), \quad$ : Pasang sampel dengan interval "h" pada sudut sepanjang titik $X_{i}$ dan $X_{i+h}$.

Jika ada 2 variabel teregenerasi " $z$ " dan "y", variogram bersama dapat diperoleh melalui:

$$
\gamma_{Z Y}(h)=\frac{1}{2 N(h)} \sum_{i=1}^{N(h)}\left[z\left(x_{i}\right)-z\left(x_{i+h}\right)\right] *\left[y\left(x_{i}\right)-y\left(x_{i}\right)-y\left(x_{i}+h\right)\right]
$$

Secara umum, prosedur membedakan antara isotropi dan anisotropi adalah sama. Penyesuaikan model variogram di sepanjang semua arah dan kemudian mendapatkan variogram berbeda beserta arahan yang berbeda. Jika mendapatkan nilai Still, Range, Nugget Effect dari semua variogram, bisa menentukan apakah data spasial itu isotropik atau anisotropik. Jika nilai Still, Range, Nugget Effect dari variogram beserta semua arah sama, maka itu adalah isotropik; Jika tidak, itu adalah anisotropik.

Anisotropi, menurut strukturnya yang berbeda, dapat dibagi menjadi Anisotropi Geometrik, Zonal Anisotropi, dan Anisotropi Campuran.

\section{DATA DAN METODE}

\subsection{Data Penelitian}

Penelitian ini menggunakan data kecepatan vertikal bulanan dengan kurun waktu 10 tahunan yaitu pad bulan Juni sampai Oktober mulai tahun 2008 - 2017 disajikan dalam bentuk spasial. Data diperoleh dari https://iridl.ldeo.columbia.edu/ dengan resolusi spasial $2,5^{\circ} \times 2,5^{\circ}$ serta pada lapisan $925 \mathrm{mb}$. Wilayah yang digunakan sebagai objek penelitian ini adalah seluruh Pulau Kalimantan yang terletak pada $5^{\circ}$ Lintang Selatan $-10^{\circ}$ Lintang Utara dan $107,5^{\circ}-120^{\circ}$ Bujur Timur. 


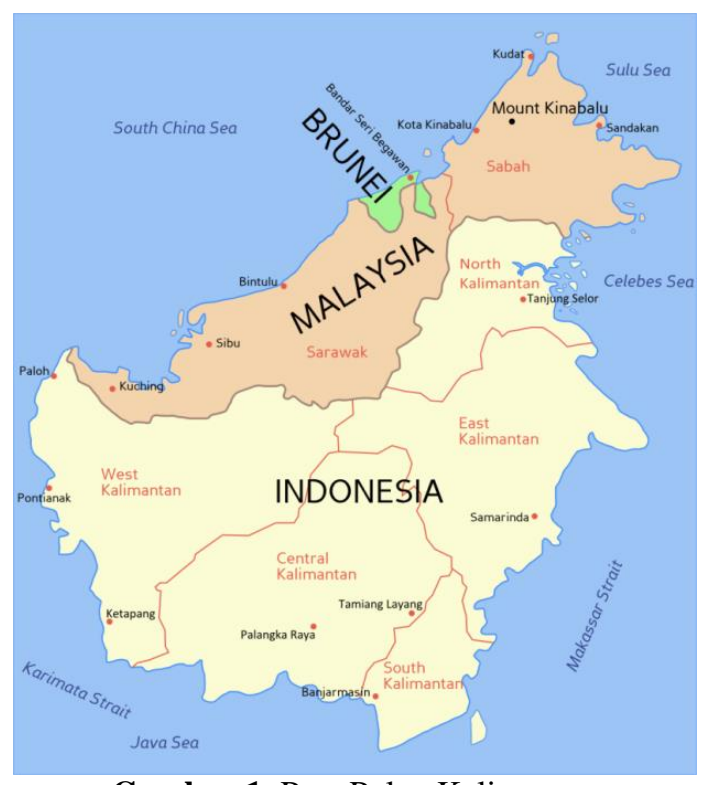

Gambar 1. Peta Pulau Kalimantan

\subsection{Metode Penelitian}

Metode yang digunakan untuk mengolah data kecepatan vertikal bulanan adalah metode variogram permukaan yang diproses melalui piranti lunak SAGA 2.1.2 . Selanjutnya hasil keluaran data tersebut dianalasis dengan metode deskriptif analitik yaitu suatu metode dalam meneliti status sekelompok manusia, suatu objek, suatu set kondisi, suatu sistem pemikiran dengan tujuan untuk membuat deskripsi, gambaran atau lukisan secara sistematis, faktual dan akurat mengenai faktafakta serta hubungan antar fenomena yang diselidiki (Nazir, 1998). Dalam penganalisisan juga mempertimbangkan anisotropi dari hasil pengolahan. Langkah - langkah mengolah data kecepatan vertikal bulanan pada Pulau Kalimantan dibagi menjadi empat tahap yaitu:

1. Mengolah data numerik menjadi tabel, pada penelitian ini menggunakan Rstatistic. Kemudian akan diperoleh data keluaran alam bentuk tabel format .xls atau .txt. Data dengan format .xls dibuka mengguakan Microsoft Excel lalu disusun dengan urutan: kolom pertama merupakan koordinat $\mathrm{x}$, kolom kedua merupakan koordinat $\mathrm{y}$, serta kolom ketiga berisikan kecepatan vertikal pada koordinat $\mathrm{x}$ dan $\mathrm{y}$. Setelah itu data disimpan dalam bentuk .csv.

2. Data kecepatan vertikal dalam bentuk .csv selanjutnya diolah menggunakan piranti lunak SAGA untuk memperoleh polanya. Pengolahan data pada SAGA menggunakan metode variogram permukaan yang sudah tersedia pada aplikasi tersebut.

3. Hasil keluaran data dari pengolahan menggunakan SAGA, berbentuk data spasial yang menunjukan pola kecepatan vertikal angin.

4. Data tersebut dianalisis menggunakan analisis anisotropi karena mempertimbangkan arah untuk analisis polanya. Hasil analisis pola kecepatan vertikal digunakan sebagai acuan dalam penempatan titik pengamatan.

\section{HASIL DAN PEMBAHASAN}

Pengolahan data dipilih di bulan Juni sampai Oktober karena menurut Mulyana (2017), kebakaran hutan dan lahan di kawasan gambut Pulau Sumatera dan Kalimantan kerap terjadi pada saat musim kemarau. Pendapat tersebut juga pernah diutarakan oleh Bahri (2002) bahwa kebakaran hutan di Indonesia selalu terjadi pada musim kemarau, yaitu pada bulan Agustus, September, dan Oktober, atau pada masa peralihan (transisi). Kecepatan vertikal yang memengaruhi persebaran asap kebakaran hutan diteliti pola setiap bulannya sehingga dapat diketahui kriteria persebaran asap akan menyebar ke wilayah tertentu.

Pola kecepatan vertikal yang telah didapatkan dari proses pengolahan data kecepatan vertikal di Pulau Kalimantan memiliki bentuk spasial berupa plot variogram yang memiliki ciri mempertimbangkan arah, sehingga analisis yang digunakan yaitu anisotropi. Suatu objek dikatan anisotropi apabila ekspansi objek tersebut berbeda dalam arahnya ketika energi termal diberikan pada objek tersebut. Pada anisotropi tingkat distribusi varians dari variabel berbeda pada masing-masing arah.

Kecepatan angin vertikal memiliki ciri khas yang sama dan dapat diinterpretasikan dalam bentuk diagonal, vertikal, dan horizontal. Plot variogram kecepatan angin vertikal dianalisis berdasarkan analisis anisotropi dengan melihat pola berwarna biru. Warna biru menandakan kecepatan vertikal bernilai negatif atau kecil yang artinya massa udara bergerak naik dan terjadi pengangkatan udara ke atas. Semakin cerah warna yang ditunjukkan atau semakin merah, maka kecepatan vertikal bernilai positif atau besar yang menandakan massa udara bergerak turun dan terjadi subsidensi (Ika dan Suyatim, 2016). Warna yang sama dan hampir sama memiliki sifat iso atau homogen, sedangkan warna yang berbeda akan 
menandakan adanya perubahan atau perbedaan nilai pada data.

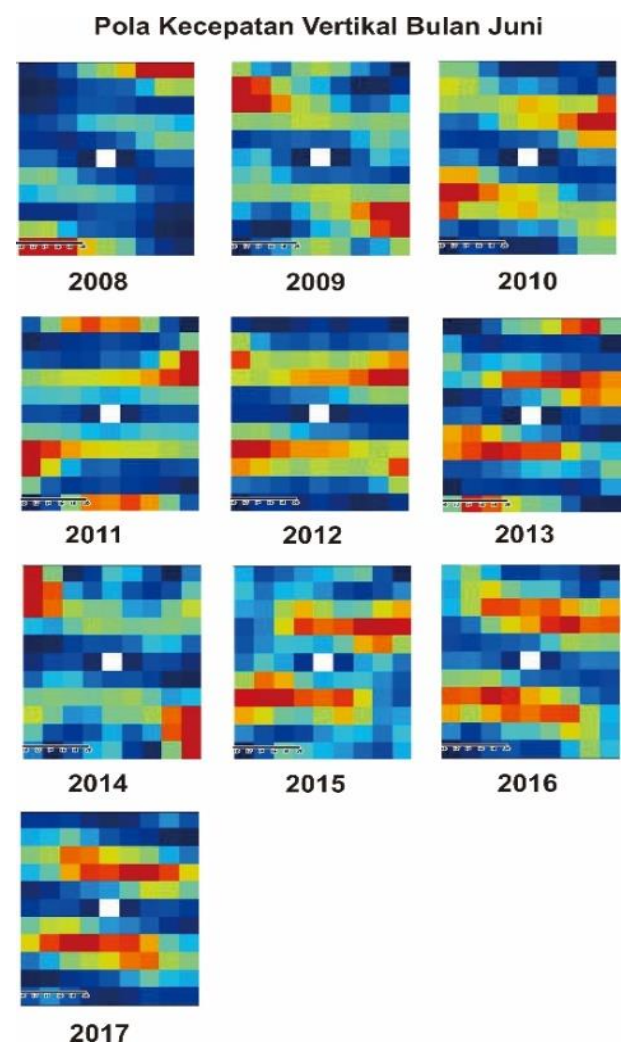

Gambar 2. Pola kecepatan vertikal di Pulau Kalimantan bulan Juni tahun 2008-2017

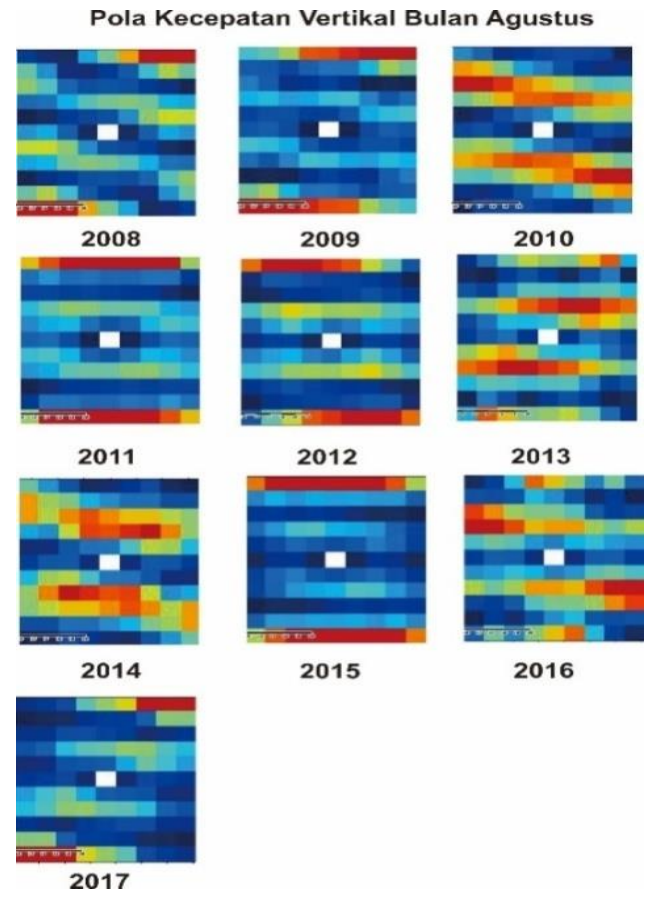

Gambar 4. Pola kecepatan vertikal di Pulau Kalimantan bulan Agustus tahun 2008-2017
Pola Kecepatan Vertikal Bulan September
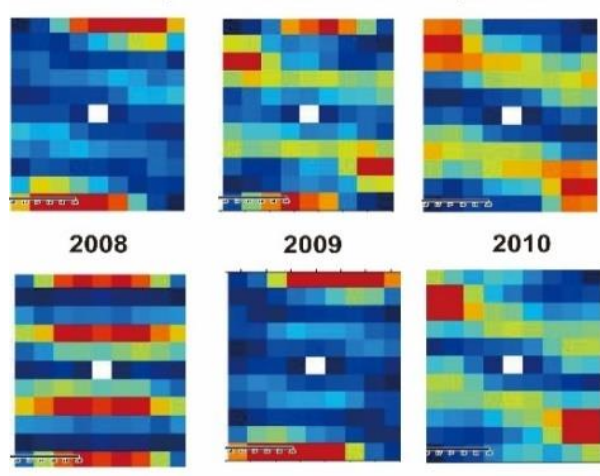

2010

2011

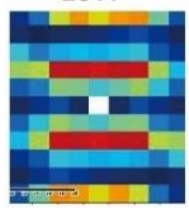

2014

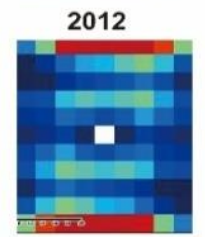

2015

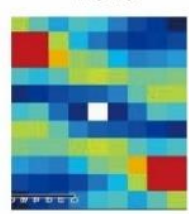

2013

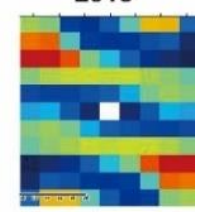

2016

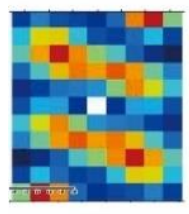

2017

Gambar 3. Pola kecepatan vertikal di Pulau Kalimantan bulan Juli tahun 2008-2017

Pola Kecepatan Vertikal Bulan Juli
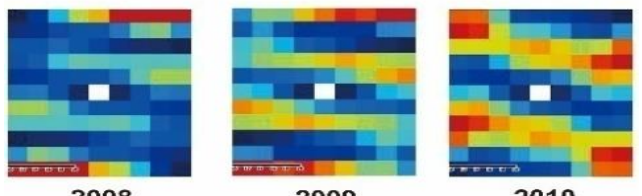

2008

2009
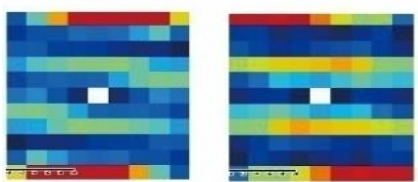

2010

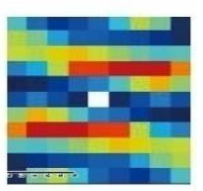

2011

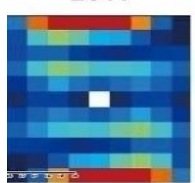

2012

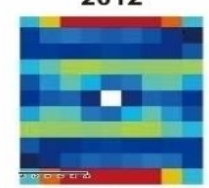

2015

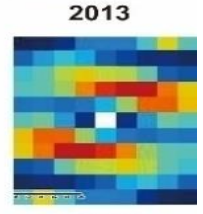

2014

2016

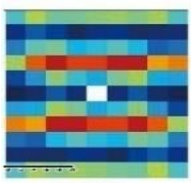

2017

Gambar 5. Pola kecepatan vertikal di Pulau Kalimantan bulan September tahun 2008-2017 
Pola Kecepatan Vertikal Bulan Oktober

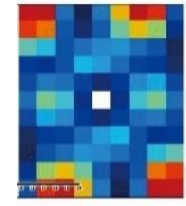

2008

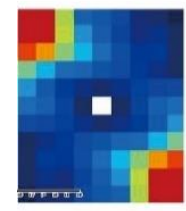

2011

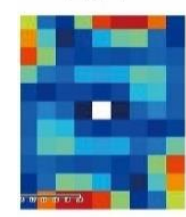

2014

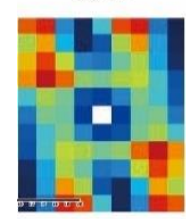

2017

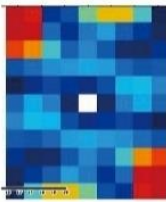

2009

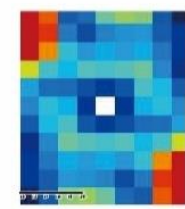

2012

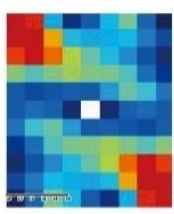

2015

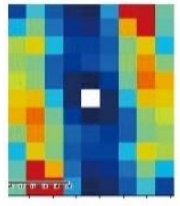

2010

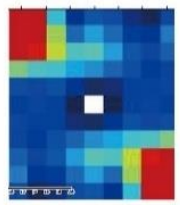

2013

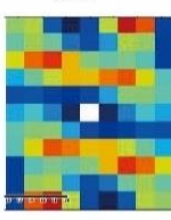

2016

Gambar 6. Pola kecepatan vertikal di Pulau Kalimantan bulan Oktober tahun 2008-2017

Tabel 1. Pola kecepatan angin vertikal di Pulau Kalimantan bulan Juni sampai Oktober

\begin{tabular}{|c|c|c|c|c|c|l|}
\hline Tahun & Jun & Jul & Agu & Sep & Okt & Keterangan \\
\hline 2008 & C & D & C & C & B & A=Utara-Selatan \\
& B=Timur laut-Barat Daya \\
\hline 2009 & B & D & D & D & B & B=Tenarat Laut \\
\hline 2010 & D & C & C & C & A & C=Tenggara-Barat \\
\hline 2011 & D & D & D & D & B & D=Timur-Barat \\
\hline 2012 & D & D & D & C & B & \\
\hline 2013 & D & C & D & C & B & \\
\hline 2014 & D & D & C & D & C & \\
\hline 2015 & D & D & D & D & B & \\
\hline 2016 & C & D & D & C & C & \\
\hline 2017 & D & D & C & C & A & \\
\hline Dominan & D & D & D & C & B & \\
\hline
\end{tabular}

Berdasarkan analisis Gambar 2 sampai Gambar 6, maka diperoleh rincian pola anisotropi dari plot variogram kecepatan vertikal Pulau Kalimantan. Tabel 1 menjelaskan bahwa bulan Juni sampai Agustus, pola kecepatan vertikal memiliki pola Timur - Barat (horizontal) yang artinya pada bulan tersebut pergerakan massa udara cenderung naik di daerah Timur - Barat Pulau Kalimantan. Pada bulan September, pola kecepatan vertikal berpola Tenggara Barat Laut sehingga bulan September pergerakan massa udaranya cenderung naik di daerah Tenggara - Barat Laut (diagonal) Pulau Kalimantan. Sedangkan pada bulan 
Oktober, Timur Laut - Barat Daya (diagonal) menjadi pola dominan sehingga pada bulan tersebut pergerakan massa udara secara vertikal cenderung naik pada daerah Timur Laut - Barat Daya Pulau Kalimantan.

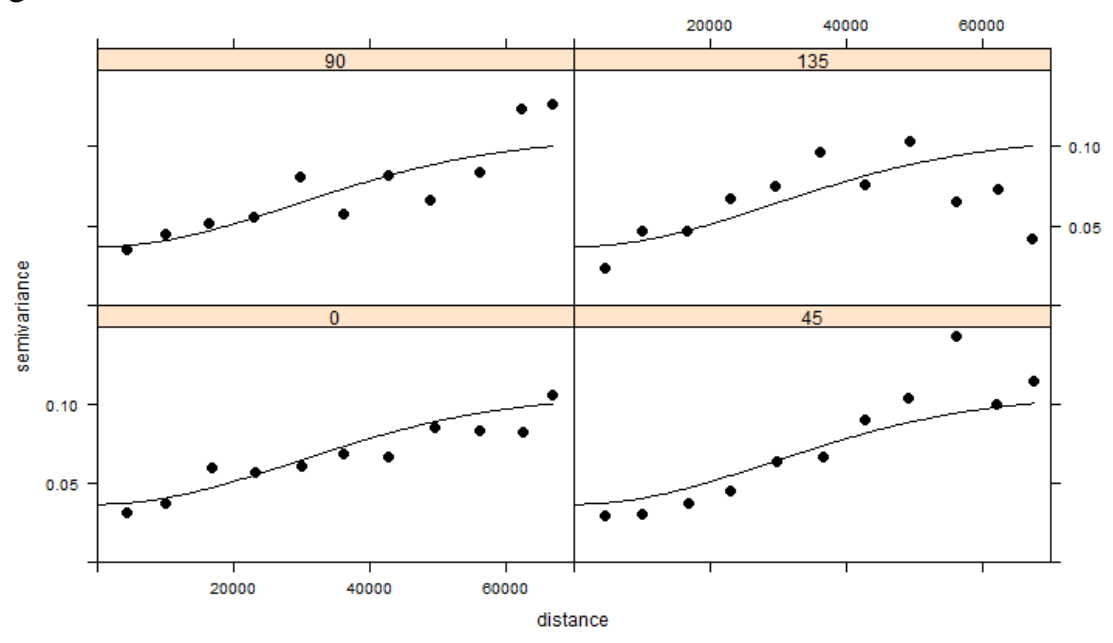

Gambar 7. Pola Variogram Horizontal (Timur - Barat)

Pola yang diperoleh dari hasil plot variogram dan analisis anisotropi dapat dijadikan sebagai pertimbangan penempatan titik pengamatan kecepatan vertikal di Pulau Kalimantan. Menurut hasil analisis, penempatan titik pengamatan harus berlawanan dengan arah pola hasil analisis. Hal ini diperlukan karena apabila alat pengamatan ditempatkan pada daerah sesuai hasil pola, maka akan lebih banyak variasi data yang tidak teramati. Pada bulan Juni sampai Agustus yang mempunyai kecenderungan pola Timur - Barat, menandakan bahwa prioritas penempatan titik pengamatan yang harus dihindari adalah pada Timur - Barat, sehingga lebih optimal

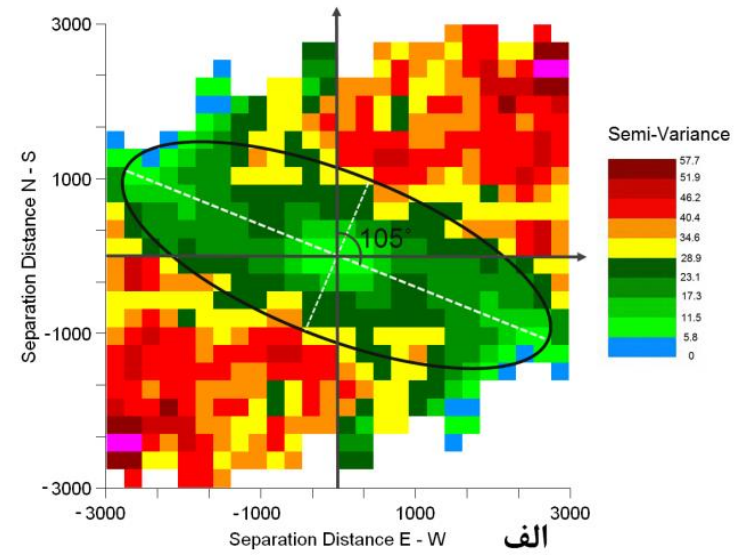

jika titik pengamatan berada pada daerah Utara - Selatan (vertikal) atau secara diagonal. Begitu pula pada bulan September dan Oktober, akan lebih baik jika titik pengamatan terletak pada daerah Utara Selatan Kalimantan, agar didapatkan data kecepatan vertikal yang bervariasi. Bentuk oval merupakan bentuk pola yang cocok dalam prioritas penempatan titik pengamatan kecepatan vertikal di Pulau Kalimantan. Pola oval yang memanjang akan dapat menampung banyak variasi data kecepatan vertikal yang berguna untuk identifikasi persebaran asap kebakaran hutan di Pulau Kalimantan agar mendapatkan hasil yang maksimal.

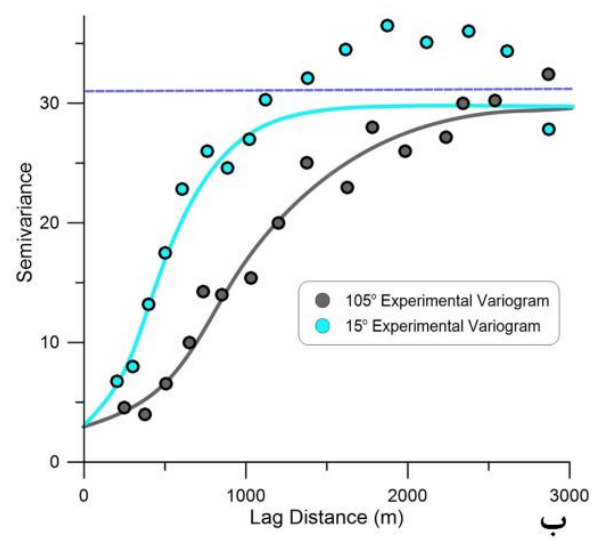

Gambar 8. Pola Oval dalam Penempatan Pengamatan Kecepatan Vertikal 


\section{KESIMPULAN DAN SARAN}

\subsection{KESIMPULAN}

Kalimantan merupakan pulau yang memiliki lahan gambut yang sangat luas dan memiliki potensi kebakaran hutan yang sangat tinggi. Penyebaran asap kebakaran hutan secara umum disebabkan oleh kondisi atmosfer baik secara horizontal maupun vertikal. Pergerakan atmosfer secara vertikal memengaruhi penyebaran asap kebakaran hutan sehingga diperlukan pengamatan yang optimal untuk mendapatkan data kecepatan angin vertikal. Pola kecepatan vertikal dianalisis menggunakan teknik analisis geostatisitik yaitu metode variogram permukaan. Dalam analisis variogram tahapan dalam perhitungan pada sejumlah lokasi \& melihat hubungan antar observasi pada berbagai lokasi yang diukur. Suatu objek dikatan anisotropi apabila ekspansi objek tersebut berbeda dalam arahnya ketika energi termal diberikan pada objek tersebut. Pada anisotropi tingkat distribusi varians dari variabel berbeda pada masing-masing arah.

Berdasarkan analisis Gambar 2 sampai Gambar 5 diperoleh dari hasil plot variogram kecepatan vertikal dan analisis anisotropi, penempatan titik pengamatan yang lebih optimal pada bulan Juni sampai Agustus berada pada daerah Utara - Selatan (vertikal). Pada bulan September dan Oktober berada pada pola oval yang memanjang. Dalam hal ini penempatan titik pengamatan harus berlawanan dengan arah pola hasil analisis agar mendapat hasil yang maksimal dalam pengamatan kecepatan vertikal untuk mitigasi dari kebakaran hutan itu sendiri di Pulau Kalimantan.

\subsection{SARAN}

Hasil penelitian ini merupakan studi awal mengenai kecepatan vertikal yang dikaitkan dengan persebaran asap kebakaran hutan di Pulau Kalimantan. Secara operasional hasil penelitian ini belum bisa dijadikan landasan teori, sehingga diperlukan studi lebih lanjut mengenai metode yang digunakan. Namun, hasil penelitian ini dapat digunakan sebagai wawasan bagi pembaca dan penulis mengenai hubungan kecepatan vertikal dengan persebaran asap kebarakaran hutan. Untuk kedepannya diharapkan akan ada penelitian lebih lanjut mengenai metode dan aplikasinya pada kecepatan vertikal yang memengaruhi persebaran asap kebakran hutan di Pulau Kalimantan. Penelitian ini diperlukan karena penempatan titik pengamatan kecepatan vertikal yang tepat dapat digunakan sebagai upaya mitigasi, sehingga dampak penyebaran asap kebakaran hutan dapat diminimalisir.

\section{DAFTAR PUSTAKA}

Desiwari, A. 2017. Pendugaan Curah Hujan Bulanan Menggunakan Metode Cokriging dengan Variogram Isotropi dan Anisotropi. Skripsi Departemen Statistika Fakultas Matematika dan Ilmu Pengetahuan Alam. IPB:Bogor.

Pandjaitan, B. S. 2015. Analisis Kejadian Mesoscale Convective Complex Di Selat Makassar (Studi Kasus Tanggal 27-28 Mei 2014). Skripsi , 1-74.

Widya, C., dan Subektyo, W. 2016. Kondisi Atmosfer Ketika Sebaran Abu Vulkanik Gunung Sinabung di Sekitar Stasiun Meteorologi Kualanamu. Jurnal Meteorologi Klimatologi dan Geofisika, 24-30.

Yulhendra, D., dan Anaperta Y. M. 2015. Estimasi Sumberdaya Batubara dengan Menggunakan Geostatistik (Krigging). Jurnal Teknologi Informasi \& Pendidikan Vol 6 (2): 168-177.

Zimmerman, D. L. 1993. Another Look at Anisotropy in Geostatistics. International Association for Mathematical Geology, 453-454.

Mulyana, E. 2017. Penyebaran Polutan dalam Kasus Kebakaran Hutan dan Lahan di Sumatera Selatan Tahun 2015. Jurnal Sains \& Teknologi Modifikasi Cuaca, Vol.18 (2) : 61-67.

Ika, Mentara, dan Suyatim. 2016. Fenomena Kabut Asap Ditinjau Data Luaran Model Arpege Synergie (Studi Kasus Tanggal 25 
dan 28 Februari 2014, Riau). Jurnal Meteorologi Klimatologi dan Geofisika, Vol 3(1) : 1-7.

Nanthini, K., Prabhakaran D., dan Ramkumar C. 2009. Efficient Forest Fire Detection System: A Spatial Data Mining. IJCSNS International Journal of Computer Science and Network Security, 100-107.

Radhakrishnan, N., dan Angayarkkani, K. 2010. An Intelligent System For Effective Forest Fire. International Journal of Computer Science and Information Security, 1-7.

Pratama, R. 2016. Pemodelan Geostatistik untuk Mengetahui Pola Distribusi $\mathrm{Hg}$ di Daerah Panas Bumi Gunung Batur, Kecamatan Kintamani, Kabupaten Bangli, Provinsi Bali, Prosiding Seminar Nasional Kebumian ke-9 : p. 103-114.

Prayoto. 2014. Analisis Kebakaran Hutan Dan Lahan Gambut Provinsi Riau Tahun 2011. Seminar International Inafor (pp. 1-8). Bogor: FORDA, FORDEF, GAFORN, dan Asosiasi Kehutanan.

Bahri, S. 2002. Kajian Penyebaran Kabut Asap Kebakaran Hutan dan Lahan di Wilayah Sumatera Bagian Utara dan Kemungkinan Mengatasinya dengan TMC. Jurnal Sains dan Teknologi Modifikasi Cuaca, Vol. 3 (2) : p. 99-104

Hariyanto, U. 2002. Analisis Upper Air Melalui Ekspansi Data Permukaan ke Level $850 \mathrm{Mb}, 700$ Mb, Dan 500 Mb. Jurnal Sains \& Teknologi Modifikasi Cuaca, p. 135-139.

http://ieeexplore.ieee.org/document/575 9552/ diakses tanggal 14 Maret 2018

http://www.supergeotek.com/Spatial_St atistical_ENG_HTML/isotropy_a nd_anisotropy.htm diakses tanggal 14 Maret 2018
https://id.wikipedia.org/wiki/Berkas:Bor neo2_map_english_names.PNG diakses tanggal 14 Maret 2018 https://iridl.ldeo.columbia.edu/ diakses tanggal 5 Februari 2018

https://lingkarankata.blogspot.co.id/2015 /01/analisis-variogram.html diakses tanggal 14 Maret 2018

https://lingkarankata.blogspot.co.id/2015 /01/geostatistik.html diakses tanggal 14 Maret 2018

https://www.researchgate.net/post/How can_I_estimate_the_major_axis_a nd_ratio_values_from_directional _variogram_for_modeling_anisotr opy diakses tanggal 16 Maret 2018 
